\title{
Cyclin D1, Id1 and EMT in breast cancer
}

\author{
Nicholas P Tobin ${ }^{1,2}$, Andrew H Sims ${ }^{3}$, Katja L Lundgren', Sophie Lehn ${ }^{1,4}$ and Göran Landberg ${ }^{1,4^{*}}$
}

\begin{abstract}
Background: Cyclin D1 is a well-characterised cell cycle regulator with established oncogenic capabilities. Despite these properties, studies report contrasting links to tumour aggressiveness. It has previously been shown that silencing cyclin D1 increases the migratory capacity of MDA-MB-231 breast cancer cells with concomitant increase in 'inhibitor of differentiation 1' (ID1) gene expression. Id1 is known to be associated with more invasive features of cancer and with the epithelial-mesenchymal transition (EMT). Here, we sought to determine if the increase in cell motility following cyclin D1 silencing was mediated by Id1 and enhanced EMT-features. To further substantiate these findings we aimed to delineate the link between CCND1, IDI and EMT, as well as clinical properties in primary breast cancer.

Methods: Protein and gene expression of IDI, CCNDI and EMT markers were determined in MDA-MB-231 and ZR75 cells by western blot and gPCR. Cell migration and promoter occupancy were monitored by transwell and ChIP assays, respectively. Gene expression was analysed from publicly available datasets.

Results: The increase in cell migration following cyclin D1 silencing in MDA-MB-231 cells was abolished by Id1 siRNA treatment and we observed cyclin D1 occupancy of the Id 1 promoter region. Moreover, IDI and SNAI2 gene expression was increased following cyclin D1 knock-down, an effect reversed with Id1 siRNA treatment. Similar migratory and SNAI2 increases were noted for the ER-positive ZR75-1 cell line, but in an Id1-independent manner. In a meta-analysis of 1107 breast cancer samples, CCND $1^{\text {low } / I D 1^{\text {high }}}$ tumours displayed increased expression of EMT markers and were associated with reduced recurrence free survival. Finally, a greater percentage of CCND1 low/ $I D 1^{\text {high }}$ tumours were found in the EMT-like 'claudin-low' subtype of breast cancer than in other subtypes.

Conclusions: These results indicate that increased migration of MDA-MB-231 cells following cyclin D1 silencing can be mediated by Id 1 and is linked to an increase in EMT markers. Moreover, we have confirmed a relationship between cyclin D1, Id1 and EMT in primary breast cancer, supporting our in vitro findings that low cyclin D1 expression can be linked to aggressive features in subgroups of breast cancer.
\end{abstract}

Keywords: Cyclin D1, Id1, EMT, breast cancer, migration, recurrence-free survival, claudin-low

\section{Background}

Cyclin D1 along with its binding partners CDK 4/6 partially mediate G1 to S-phase transition of the cell cycle through phosphorylation and inactivation of retinoblastoma $(\mathrm{Rb})$ protein with subsequent release of E2F transcription factors [1-3]. The oncogenic activities of the protein have been addressed in numerous studies, [4-7] and many human cancers including breast, colon, and prostate, overexpress cyclin D1 [8-10]. More recently, a

\footnotetext{
* Correspondence: glandberg@picr.man.ac.uk

'Breakthrough Breast Cancer Research Unit, School of Cancer, Enabling Sciences and Technology, University of Manchester, Manchester Academic Health Science Centre, Paterson Institute for Cancer Research, The Christie NHS Foundation Trust, Wilmslow Road, Manchester, M20 4BX, UK Full list of author information is available at the end of the article
}

number of cyclin D1 studies in breast cancer have focused on functions that are not directly related to cell cycle maintenance. Cyclin D1 can modulate the activity of transcription factors and histone deacetylase [11], it can activate oestrogen receptor in the absence of oestrogen [12], and it can bind to the upstream regulatory region of the diverse Notch1 gene [13]. Previous work by our group revealed a novel induction of breast cancer cell migration after cyclin D1 silencing, which may account for a worse clinical outcome for patients with low expression of the protein [14]. Of the genes upregulated following this silencing, Inhibitor of differentiation 1 (Id1), a basic helix-loop helix (bHLH) family member, represents a potential candidate modulating the effect of cyclin D1 on cell migration.

\section{Biomed Central}

(c) 2011 Tobin et al; licensee BioMed Central Ltd. This is an Open Access article distributed under the terms of the Creative Commons Attribution License (http://creativecommons.org/licenses/by/2.0), which permits unrestricted use, distribution, and reproduction in any medium, provided the original work is properly cited. 
The four Id proteins (termed 1-4) represent the class $\mathrm{V}$ subgroup of the bHLH family, however in contrast to other bHLH transcription factors (that modulate gene expression though dimerization and DNA binding of canonical E-box promoter regions in target genes [15]), the Id proteins lack a DNA binding domain and instead bind to other bHLH family monomers, negatively regulating their activity [16]. Id1 has been associated with breast cancer progression in a number of studies. ID1 promoter regulation is lost in aggressive breast cancer cells [17], Id1 is associated with induction of cell proliferation and invasion [18], and stable antisense targeting of Id1 represses an aggressive and metastatic phenotype in mammary epithelial cells [19]. Recent data has also revealed that cyclin D1 binds to the ID1 promoter region in the mammary gland, and negatively regulates its transcription in mouse retina [13]. Given the role of Id1 in cell invasion and metastasis, it represents a strong candidate for driving breast cancer cell migration following cyclin D1 silencing.

Increased motility and invasiveness are inherent properties of a mesenchymal phenotype [20], and the process whereby a non-motile epithelial cell procures these traits is termed epithelial to mesenchymal transition (EMT). Recently, a role for EMT in the process of cancer metastasis has been postulated, and direct evidence of EMT has been demonstrated in a mouse mammary tumour model [21]. A number of distinct changes occur during the transition to a mesenchymal phenotype, most notably the down-regulation of epithelial markers such as Ecadherin, and an upregulation of mesenchymal markers including Snail, Slug, vimentin, Twist and fibronectin [22]. In addition, a number of phenotypic changes occur including loss of cell polarity and tight junction regulation, accompanied by cytoskeletal changes [23,24] and enhanced cell migration/invasion [25]. Id1 has previously been implicated with EMT both directly, through suppression of E-cadherin and zonula occludins-1 (ZO-1), in human kidney cells [26] and indirectly, through loss of Krueppel-like factor 17 (KLF17) in breast cancer cells [27]. As such, we wished to clarify whether the increase in cell migration following cyclin D1 silencing was due to an Id1-dependent increase in EMT markers.

In this study, we demonstrate that silencing Id1 prevents the cyclin D1 mediated increase in MDA-MB-231 breast cancer cell migration. We have identified that an increase in SNAI2 mRNA expression following cyclin D1 silencing is abolished in cyclin D1/Id1 double knock-down cells. A meta-analysis of primary breast tumours revealed significant associations between CCND1, ID1, CDH1 (E-cadherin) and recurrence-free survival. CCND1 and ID1 gene expression was also correlated with EMT-associated genes including, VIM,
SNAI1, SNAI2, and TWIST1. Finally, the recently established claudin-low subtype of breast cancer, which is enriched in EMT markers, was found to have a fourfold greater proportion of $C C N D 1^{\text {low }} / I D 1^{\text {high }}$ tumours compared to other breast cancer subtypes.

\section{Methods}

\section{Cell culture}

The human breast cancer cell lines MDA-MB-231 and ZR75-1 (ATCC, Int., Manassas, VA) were maintained in RPMI 1640 medium supplemented with $10 \%$ fetal calf serum (FCS), sodium pyruvate $(1 \mathrm{mM})$ and $1 \times$ PEST (streptomycin $90 \mu \mathrm{g} / \mathrm{ml}$, penicillin $90 \mathrm{IU} / \mathrm{ml}$ ). Cells were maintained in a humidified atmosphere of $5 \% \mathrm{CO}_{2} / 95 \%$ air at $37^{\circ} \mathrm{C}$.

\section{siRNA and vector transfections}

$7.5 \times 10^{5}$ cells were seeded in a $10 \mathrm{~cm}\left(47.16 \mathrm{~cm}^{2}\right)$ culture dish with PEST-free serum-containing media (SM) for $24 \mathrm{~h}$. The media was subsequently removed and PEST-free serum-free media (SFM) added along with 1 ml siRNA solution (OptiMEM, Gibco, Lipofectamine 2000, Invitrogen Life Technologies, Carlsbad, CA) giving a final concentration of $40 \mathrm{nM}$ oligonucleotides. $5 \mathrm{~h}$ after transfection, SFM was replaced with SM and cells were allowed to grow for $20 \mathrm{~h}$ before harvesting for migration assay or western blot. ON-TARGETplus SMARTpool siRNA targeting cyclin D1, Id1 or Slug (Dharmacon RNA Technologies, Lafayette, CO) were included as standard experimental protocol. A non-targeting pool was used as negative control. For vector experiments, cells were treated as above with the following exceptions: seeding density was $11 \times 10^{5}$ cells in a $47.16 \mathrm{~cm}^{2}$ culture dish and $1.5 \mu \mathrm{g}$ of Id 1 vector $\mathrm{pCMV-}$ SPORT6 or control vector pCMV6 was used (Invitrogen Life Technologies, Carlsbad, CA).

\section{Western blotting}

Western blot was performed as previously described [28] with the following antibodies: anti-cyclin D1 (1:500, DCS-6, DAKO, Denmark), anti- Id1 (1:400, C-20, Santa Cruz), and anti-Actin (1:1000, I-19, Santa Cruz, CA, USA) Proteins were visualized with horseradish peroxidase conjugated secondary antibodies using the enhanced chemiluminescence detection system (Amersham Pharmacia Biotech, Little Chalfont, UK).

\section{Migration assays}

Cell migration was routinely carried out in $8 \mu \mathrm{m}$-pore polycarbonate membrane Transwell chambers with a diameter of $6.5 \mathrm{~mm}$ (Corning, Inc. Corning, NY). The membranes were incubated in $150 \mu \mathrm{l}$ serum-free RPMI 1640 for an initial equilibrium period of $1 \mathrm{~h}$. Cells were resuspended in serum-free medium $\left(1 \times 10^{6}\right.$ cells $\left./ \mathrm{ml}\right)$ 
and 100,000 cells were added to each migration chamber. The chambers were placed into wells containing $600 \mu \mathrm{l} 10 \%$ FCS medium and cells were allowed to migrate for $4 \mathrm{~h}$ after siRNA or vector transfections. Cells remaining in the chamber were removed with a cotton swab and the migrated cells situated on the lower side of membranes were fixed for $15 \mathrm{~min}$ in PBS containing 4\% paraformaldehyde. Membranes were cut and mounted on glass slides for DAPI staining and counted using a fluorescent microscope (cells in three 10X-magnification fields representing the composition of the membrane were counted). Assays were performed in triplicate with two migration membranes for every treatment, and the total number of migrated cells was used for graphical and statistical purposes.

\section{qPCR and Chromatin immunoprecipitation assay (ChIP)}

Total RNA was isolated using an RNeasy Plus Kit (Qiagen, West Sussex, UK). RNA was eluted and quantified using a Nanodrop spectrometer (ThermoScientific, Leicestershire, UK). The reverse transcription step was performed using the TaqMan Reverse Transcription Reagent Kit (Applied Biosystems, CA, USA) according to manufacturer's guidelines. TaqMan real time PCR was designed using the Universal Probe Library (Roche Diagnostics, West Sussex, UK). Primers and sequences can be found in Additional File 1. RT-PCR was performed with $5 \mathrm{ng}$ template cDNA using Taqman Master Mix (Applied Biosystems, CA, USA) and an ABI prism $7900 \mathrm{HT}$ sequence detection system (Applied Biosystems, CA, USA). ChIP assay was carried out using the MAGnify ${ }^{\mathrm{TM}}$ Chromatin Immunoprecipitation System (Invitrogen Life Technologies, Carlsbad, CA). $3 \mu \mathrm{g}$ of anti-cyclin d1 antibody (DCS-6, DAKO, Denmark) was used to pull down cyclin D1, with subsequent detection of Id1 using SimpleChIPTM Human Id1 Promoter Primers (Cell Signalling Technology, Danvers, MA) and Mrg1 as positive control (Eurofins Laboratories Ltd., Manchester, UK). Promoter occupancy was calculated based on the ratio of ChIP to input control.

\section{Microarray analysis}

Gene expression analysis of cyclin D1 silenced cells was described previously [14]. All data is MIAME compliant and raw data has been deposited at the NCBI Geo database (Accession number GSE27260). A meta-analysis of six Affymetrix gene expression datasets comprising a total of 1107 primary human breast cancers was performed as previously described [29]. Clinicopathological features were retrieved from the original studies. The follow up endpoints for the Chin et al., Pawitan et al. and Sotoriou et al. datasets were recurrence-free survival, whereas for Desmedt et al., Ivshina et al. and Wang et al. datasets it was disease-free survival. The gene expression datasets of Herschkowitz et al. [30] and Neve et al. [31] were used to compare expression of ID1, CCND1 and EMT-related genes across the breast cancer subtypes, including claudin-low as determined by the study and breast cell lines respectively.

\section{Statistical methods}

To examine the statistical significance of the differences seen in the Boyden migration and qPCR a two-tailed student's t-test was employed, assuming unequal variance. Unless noted otherwise, the standard error of the mean is stated. Statistical analyses were performed using SPSS software (version 17.0, SPSS, Chicago, IL, USA). For examination of the statistical significance of associations between CCND1, ID1 and other categorical variables, Spearman's rank-order correlation coefficient, Kruskal-Wallis and Wilcoxon/Mann-Whitney tests were used as indicated in figure legends. To study recurrence-free survival the Kaplan-Meier method was employed and to compare recurrence-free survival among different quartiles the log-rank test was used. For claudin-low subtype comparison a $\mathrm{Chi}^{2}$ test was employed.

\section{Results}

\section{Cyclin D1 and Id1 in breast cancer cell migration}

We have previously shown that cyclin D1 silencing increases migration of the ER-negative MDA-MB-231 breast cancer cell line, an effect not observed when silencing its binding partners CDK 4/6 (Lehn et al. 2010). ID1 was among the genes most significantly upregulated (Figure $1 \mathrm{~A}, 1.40 \pm 0.007$ fold) in response to cyclin D1 knock-down (Figure 1A, $0.22 \pm 0.017$ fold) and was unchanged following CDK $4 / 6$ silencing. As a role for Id1 in breast cancer cell metastasis and aggressiveness has previously been suggested [17], it was logical to examine whether it was also responsible for the cyclin D1 induced increase in cell migration. Western blotting confirmed an increase in Id1 protein following cyclin D1 siRNA treatment, and effective cyclin D1 and Id1 silencing (Figure 1B). In addition, neither Id1 silencing nor vector overexpression altered cyclin D1 protein levels after $24 \mathrm{~h}$.

Boyden chamber migration assays accurately replicated previous experimental results, with cyclin D1 siRNA treatment of MDA-MB-231 cells increasing the total number of migrated cells to $53.57 \pm 3.5$, compared to control levels of $41.89 \pm 3.0$ (Figure 1C). Notably, Id1 siRNA decreased cell migration (31.13 \pm 1.99$)$, and addition of cyclin D1 siRNA was unable to significantly rescue this effect $(46.00 \pm 2.34)$. Overexpression of Id1 increased migration $(67.13 \pm 3.82$ compared to control of $36.33 \pm 4.00)$ and similar effects were found when treating cells with both Id1 vector and cyclin D1 siRNA $(67.24 \pm 6.08)$. To discount the possibility that increased 


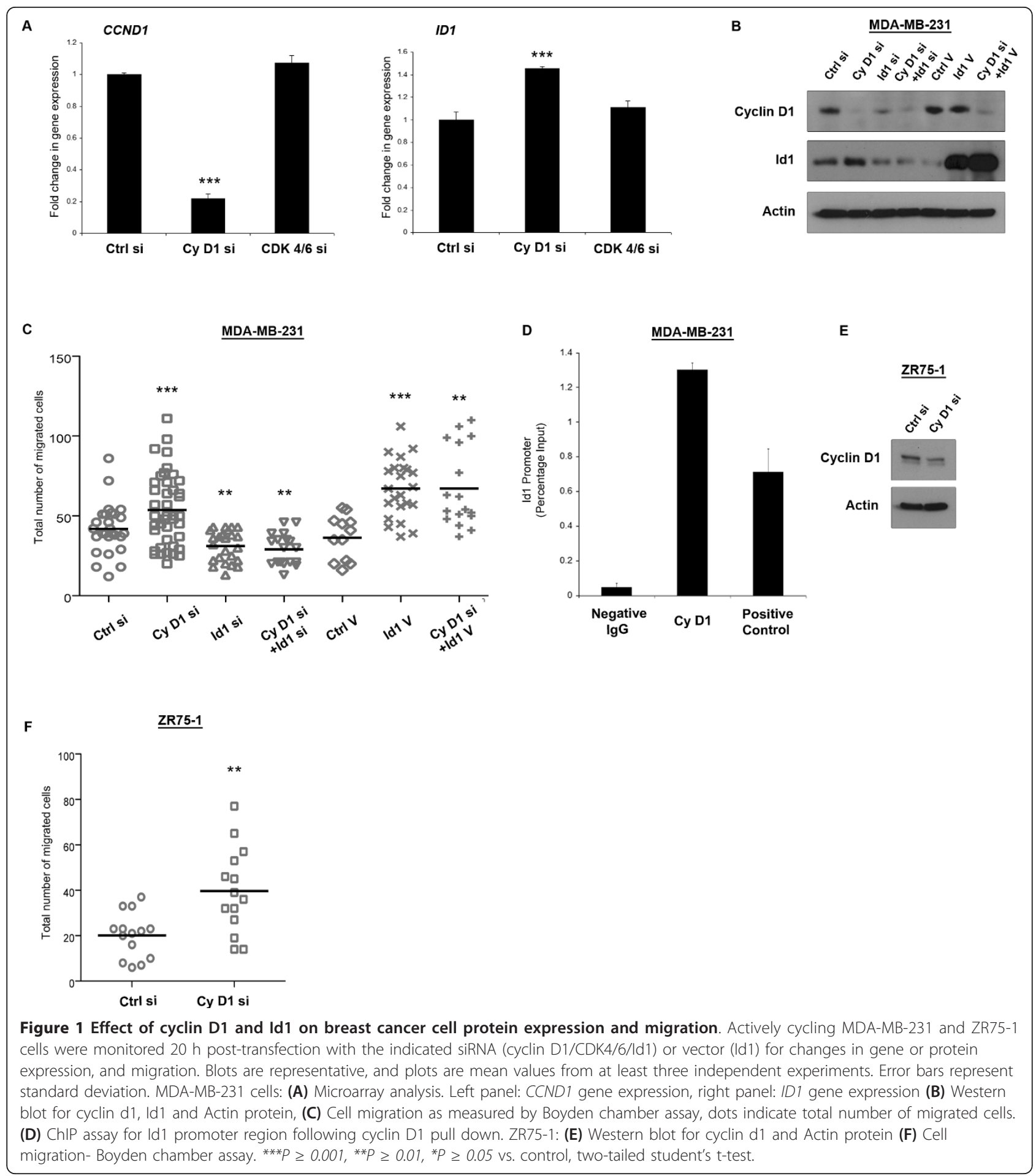

siRNA concentration may have a negative impact on migration in the cyclin D1 and Id1 siRNA treated cells, we assessed single and double concentrations of siRNA in control cells and found no significant difference in cell migration (data not shown). To determine if Id1 could be a transcriptional target of cyclin D1 in MDA-
MB-231 cells, we performed a ChIP assay, and demonstrated that cyclin D1 occupancy in the Id1 promoter was significantly higher $(1.30 \%$ of input) in cyclin D1 pull-down than in a negative mouse IgG control, and higher still than the positive control Mrg1 (Bienvenu et al. 2010) (Figure 1D). 
We next examined whether cyclin D1 silencing could effect migration in an ER-positive breast cancer cell line with similar cyclin D1 levels to MDA-MB-231 cells. siRNA treatment against cyclin D1 reduced its protein levels (Figure 1E) and also significantly increased migration (39.71 \pm 5.04 compared to control of 20.14 \pm 2.66 , Figure 1F) of ZR75-1 cells. However, given the extremely low protein expression levels of Id1 in ZR75-1 cells, it is unlikely that the increase in migration is mediated through Id 1 in this cell line. In addition to the interaction we have demonstrated between cyclin D1 and Id1, other regulators of Id1 have been previously identified. TGF-beta [32], KLF17 [33] and Src [34] are all known to interact and influence Id1 expression. Thus, levels of Id1 protein in ZR75-1 cells may reflect interactions with other transcriptional regulators. To directly address this, we examined TGF-beta (a known inducer of Id1 [32]) gene expression in a range of breast cancer cell lines and noted high levels in MDA-MB-231 cells relative to ZR75-1 cells (Additional file 2). Importantly, none of the aforementioned transcripts were altered in our expression array data in response to cyclin D1 silencing and are hence unlikely to contribute to the migratory effect we have observed.

Together, these data indicate that the increase in Id1 following cyclin D1 silencing in MDA-MB-231 cells is responsible for their enhanced migratory capacity, but that this does not appear to be the only mechanism by which cyclin D1 can induce cell migration. Mounting evidence has indicated the occurrence of an EMT-like phenotype in migratory breast cancer cells $[35,36]$. Given this evidence we wished to determine whether the Id1 induced increase in migration following cyclin D1 silencing may be mediated through enhanced features of EMT.

\section{Cyclin D1 silencing in MDA-MB-231 cells increases EMT gene expression in an Id1 dependent manner}

Examination of EMT-related genes in the microarray analysis of MDA-MB-231 cells showed significant increases in SNAI2 (1.19 \pm 0.03 fold), CDH11 (OB-Cadherin, $1.18 \pm 0.03$ fold), and TWIST1 (1.13 \pm 0.05 fold), following cyclin D1 silencing. A modest increase in SNAI2 (1.06 \pm 0.01 fold) expression was noted after CDK4/6 silencing, but neither siRNA treatment had an effect on SNAI1 or VIM expression (Figure 2A).

Using siRNA against cyclin D1 and Id1 we confirmed significantly decreased levels of CCND1 by qPCR, and found that Id 1 siRNA had no significant impact on CCND1 expression (Figure 2B) after $24 \mathrm{~h}$. Increased ID1 levels $(1.58 \pm 0.09$ fold $)$ were noted following cyclin D1 silencing (Figure $2 \mathrm{C}$ ) and the effect of Id1 siRNA on ID1 expression was reduced when combined with cyclin D1 siRNA $(0.18 \pm 0.01$ vs. $0.28 \pm 0.06$ fold respectively,
$P=0.019)$. As noted in our microarray data, cyclin D1 silencing increased SNAI2 levels, a result validated by qPCR analysis (1.41 \pm 0.1 fold). This increase was reversed when cyclin D1 was silenced in combination with Id1 (0.73 \pm 0.13 fold of control, Figure 2D). Id1 overexpression increased SNAI2 levels (1.34 \pm 0.22 fold), an effect greatly enhanced when cyclin D1 was also silenced (2.39 \pm 0.64 fold). Notably, silencing of cyclin D1 was unable to increase MDA-MB-231 cell migration when Slug was also silenced (Additional File 3). We also observed an increase in SNAI2 expression following cyclin D1 silencing (Figure 2E) in ZR75-1 cells (1.34 \pm 0.05 fold, Figure 2F).

These results suggest a novel effect whereby cyclin D1 silencing enhances a mesenchymal phenotype in MDAMB-231 and ZR75-1 cells. In order to further validate our hypothesis, we next examined gene expression data from a large cohort of breast cancer patients.

\section{CCND1 and ID1 expression are correlated to clinicopathological parameters and predict recurrence risk in breast cancer}

To investigate the relationship between CCND1 and ID1 expression in primary breast tumours we used a previously published meta-analysis consisting of six groups of tumours on Affymetrix arrays totaling 1107 samples. Due to the large number of patients and spread of gene expression values we quartiled each gene, giving us the following subgroups- 1 (low expression), 2 (low-medium), 3 (medium-high) and 4 (high). Initial examination of clinicopathological parameters revealed that ID1 was negatively correlated to tumour grade $(\mathrm{p}<0.001)$, and size $(\mathrm{p}=0.005)$. CCND1 expression was associated with ER-positive breast cancers $(\mathrm{p}<0.001)$, and lower histological grade $(\mathrm{p}=0.002)$ (Table 1$)$. Neither CCND1 nor ID1 provided independent prognostic information in a Cox multivariate analysis (data not shown).

Next, we determined how these quartiles related to recurrence-free survival (RFS) in the combined datasets. In all patients, and particularly in the subgroup of ERpositive patients, high expression of CCND1 was associated with the shortest RFS $(p=0.049$ and $p=0.006$, respectively, Figure 3A, left and middle panels, log-rank test). This effect was not observed in the ER-negative subgroup (Figure 3A, right panel). Conversely, low ID1 expression was associated with the shortest RFS in all patients ( $\mathrm{p}<0.001$, Figure $3 \mathrm{~B}$, left panel), but not in the ER-positive and negative subgroups (Figure 3B, middle and right panels). The levels of EMT-related genes, SNAI1 (Figure 3C), SNAI2 (Figure 3D), VIM or TWIST (Additional File $4 \mathrm{~B}$ and $4 \mathrm{C}$ ) were not of significant prognostic value. However, CDH1 (E-cadherin) significantly predicted RFS in all and ER-positive patients (Additional File 4A, left and middle panels). 
A
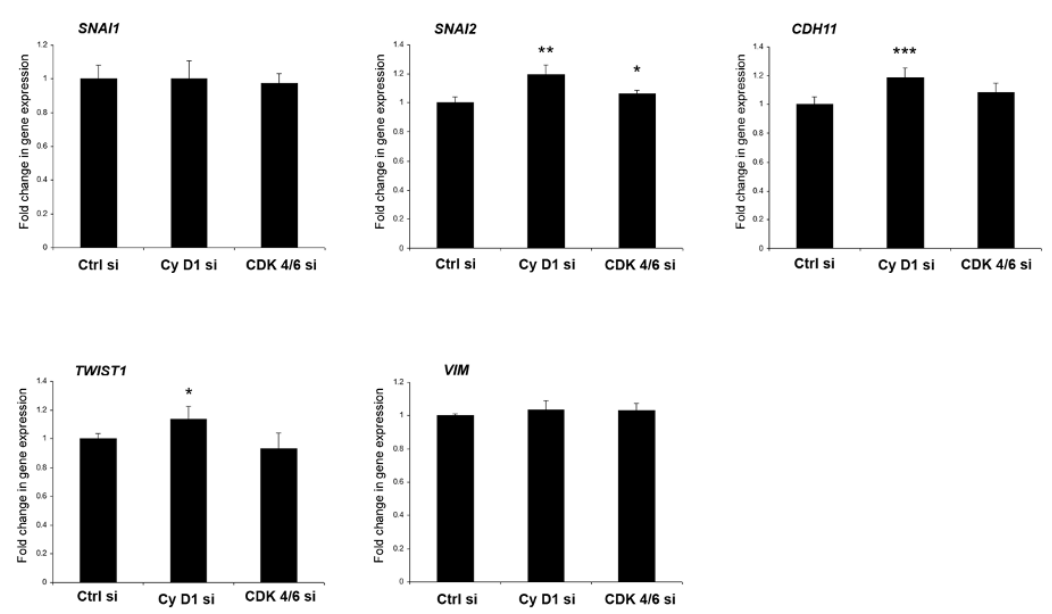

B

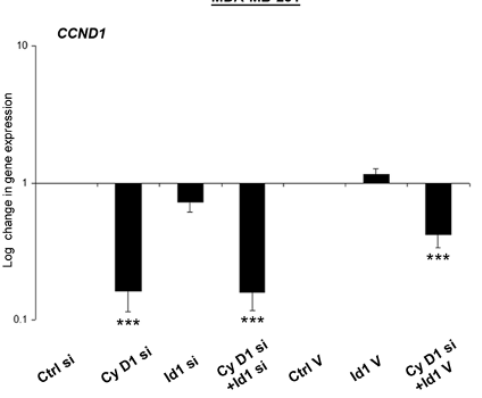

C

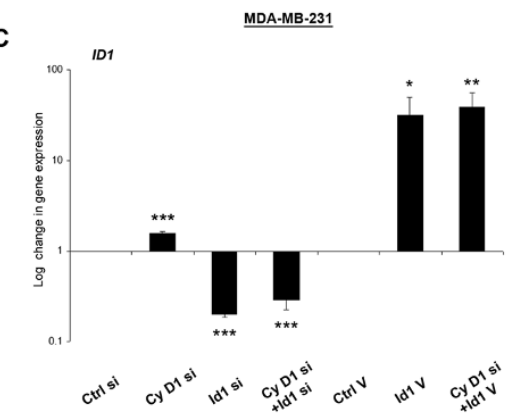

D
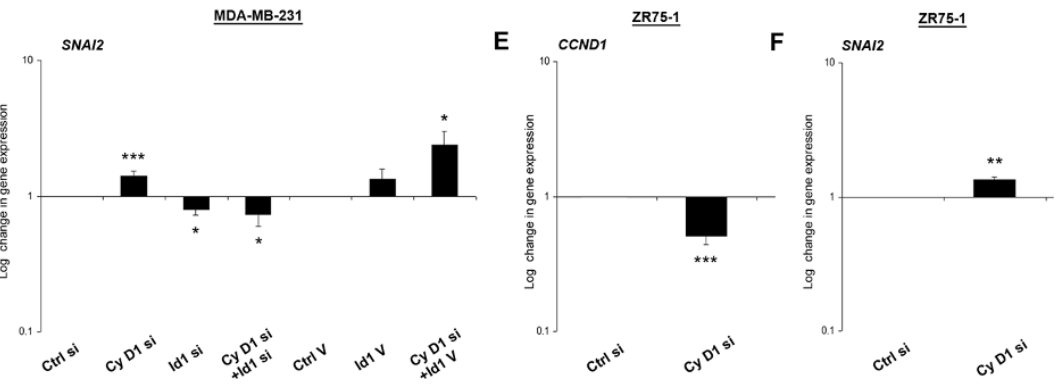

Figure 2 Effect of cyclin $\mathbf{d} 1$ and Id 1 on EMT markers. MDA-MB-231 cells were monitored $20 \mathrm{~h}$ post-transfection with the indicated siRNA (cyclin D1/CDK4/6/ld1) or vector (Id1) for changes in EMT-related gene expression by microarray analysis. Additionally, MDA-MB-231 and ZR75-1 gene expression was examined by qPCR assay. Plots are mean values from at least three independent experiments Error bars represent standard deviation. (A) Microarray analysis of SNAI1, SNAI2, CDH11, TWIST1 and VIM gene expression. (B-D) CCND1, IDI and SNAI2 in MDA-MB-231 cells. (E, F) $\mathrm{qPCR}$ analysis of CCND1 and SNA12 in ZR75-1 cells. ${ }^{* *} P \geq 0.001,{ }^{* *} P \geq 0.01,{ }^{*} P \geq 0.05$ vs. control, two-tailed student's t-test.

Low CCND1 and high ID1 expressing tumours show increased EMT-related gene expression and predict risk of recurrence in breast tumours

As our in vitro experiments indicated that $C C N D 1^{\text {low }}$ / $I D 1^{\text {high }}$ breast cancer cells exhibit increased invasion and expression of the SNAI2 gene, and our survival analysis indicated that low CCND1 and high ID1 expression can predict RFS in breast cancer patients; we examined all four combinations of $C C N D 1^{\text {low/high }}$ and ID $1^{\text {low/high }}$ gene expression in relation to well-characterised EMT genes in all patients of the same tumour material. The highest expression of SNAI2, TWIST1, VIM and lowest expression of $C D H 1$ was found in the $C C N D 1^{\text {low }} / I D 1^{\text {high }}$ subgroup of tumours (Figure 4A, yellow bars). Further weight was added to this analysis when examining the $C C N D 1^{\text {low/high }} / I D 1^{\text {low }}$ subgroups of tumours (Figure $4 \mathrm{~A}$, red and blue bars, respectively). These tumours encompass the lowest expression of SNAI2, TWIST1, VIM and highest expression of $C D H 1$. This suggests, as our MDA-MB-231 in vitro experiments demonstrated, that cyclin D1 is unable to influence the induction of EMT in the absence of Id1. 
Table 1 Distribution of CCND1 and ID1 gene expression according to clinico- pathological parameters in breast cancer patients

\begin{tabular}{|c|c|c|c|c|c|c|c|c|c|c|}
\hline \multirow[b]{2}{*}{ Variable } & \multicolumn{4}{|c|}{ CCND1 } & \multicolumn{6}{|c|}{ ID1 } \\
\hline & $\begin{array}{c}1 \\
N=277 \\
\end{array}$ & $\begin{array}{c}2 \\
N=276 \\
\end{array}$ & $\begin{array}{c}3 \\
N=277 \\
\end{array}$ & $\begin{array}{c}4 \\
N=277 \\
\end{array}$ & & $\begin{array}{c}1 \\
N=277 \\
\end{array}$ & $\begin{array}{c}2 \\
N=276 \\
\end{array}$ & $\begin{array}{c}3 \\
N=277 \\
\end{array}$ & $\begin{array}{c}4 \\
N=277 \\
\end{array}$ & \\
\hline $\begin{array}{l}\text { ER } \alpha \text { positive (\%) } \\
P \text {-value } \\
\text { (R-value) }\end{array}$ & & & & & $\begin{array}{c}<0.001 \dagger \\
(0.306)\end{array}$ & & & & & $\begin{array}{l}0.529+ \\
(0.021)\end{array}$ \\
\hline$<10$ & 118 & 49 & 44 & 28 & & 61 & 66 & 52 & 60 & \\
\hline$\geq 10$ & 117 & 177 & 195 & 211 & & 172 & 170 & 182 & 176 & \\
\hline \multicolumn{11}{|l|}{ Missing cases: 168} \\
\hline $\begin{array}{l}\text { NHG } \\
\text { P-value } \\
\text { (R-value) }\end{array}$ & & & & & $\begin{array}{c}0.002 \\
(-0.098)\end{array}$ & & & & & $\begin{array}{l}<0.001 \\
(-0.199)\end{array}$ \\
\hline I & 27 & 48 & 60 & 32 & & 22 & 41 & 44 & 60 & \\
\hline$\|$ & 72 & 79 & 86 & 93 & & 77 & 78 & 87 & 88 & \\
\hline III & 96 & 73 & 53 & 65 & & 90 & 84 & 62 & 51 & \\
\hline \multicolumn{11}{|l|}{ Missing cases: 323} \\
\hline $\begin{array}{l}\text { Lymph node status } \\
P \text {-value } \\
\text { (R-value) }\end{array}$ & & & & & $\begin{array}{l}0.360 \dagger \\
(0.030)\end{array}$ & & & & & $\begin{array}{c}0.078+ \\
(-0.058)\end{array}$ \\
\hline$N=0$ & 192 & 198 & 200 & 190 & & 190 & 190 & 197 & 203 & \\
\hline$N>0$ & 41 & 30 & 39 & 47 & & 43 & 48 & 33 & 33 & \\
\hline \multicolumn{11}{|l|}{ Missing cases: 170} \\
\hline $\begin{array}{l}\text { Tumour size, mm } \\
P \text { - value } \\
\text { (R-value) }\end{array}$ & & & & & $\begin{array}{c}0.415 \dagger \\
(-0.032)\end{array}$ & & & & & $\begin{array}{c}0.005 \dagger \\
(-0.109)\end{array}$ \\
\hline$\leq 20$ & 71 & 90 & 97 & 80 & & 63 & 91 & 89 & 95 & \\
\hline$>20$ & 90 & 75 & 73 & 86 & & 95 & 83 & 69 & 77 & \\
\hline Missing cases: 445 & & & & & & & & & & \\
\hline
\end{tabular}

* Correlations were calculated using Spearman's $\rho$ unless otherwise specified

† Wilcoxon/Mann-Whitney test (two-sided)

ER, Oestrogen receptor; NHG, Nottingham Histologic Grade.

To gain further insight into the relationship between cyclin D1 and Id1 we examined the $C C N D 1^{\text {low }} / I D 1^{\text {high }}$ subgroups with regards to RFS in all, ER-positive, and negative patients. No statistical significance was found when examining all (data not shown) or ER-negative patients however, high ID1 expression was associated with the shortest RFS (Figure 4B, left and right panels) in $C C N D 1^{\text {low }}$ ER-positive tumours. In addition, both low and high CCND1 expression was associated with the shortest RFS in $I D 1^{\text {high }}$ ER-positive tumours with no statistical significance observed in all (data not shown) or ER-negative patients (Figure 4C, left and right panels).

\section{Low CCND1 and high ID1 expression is dominant in the EMT-related basal B breast cancer cell lines and claudin- low subtype of tumours}

A number of studies [31,37-39] have consistently split breast cancer cell lines into three groups based on their gene expression profiles; luminal, basal (or basal A) and mesenchymal/basal B/claudin-low subtypes. A greater proportion of the mesenchymal/basal B/claudin-low cell lines have low CCND1 and high $I D 1$ expression than luminal (including ZR75-1) or basal A subtypes (Figure $5 \mathrm{~A}-\mathrm{C}$ ) in the Neve et al. dataset (profiles for the same cell lines are highly correlated across several independent studies, data not shown) and have increased expression of EMT markers (SNAI1, SNAI2, TWIST1, VIM), along with low CDH1. Although ZR75-1 cells have similar levels of $C C N D 1$, they are of luminal subtype and display high expression of $C D H 1$ (Figure 5A). This demonstrates the distinct difference between these cells lines, which may explain why Id1 appears unnecessary for enhanced EMT features in ZR75-1 cells following cyclin D1 silencing.

Recent studies have identified a 'claudin-low' subtype of breast cancer amongst human tumours through gene transcriptional profiling $[30,40,41]$. Tumours of the claudin-low subtype putatively contain tumour initiating cells (TIC), display high expression of EMT markers, and are believed to be the closest representation of an EMT phenotype in breast cancer [42]. This subtype displayed the highest proportion of CCND1 $1^{\text {low }} / I D 1^{\text {high }}$ 

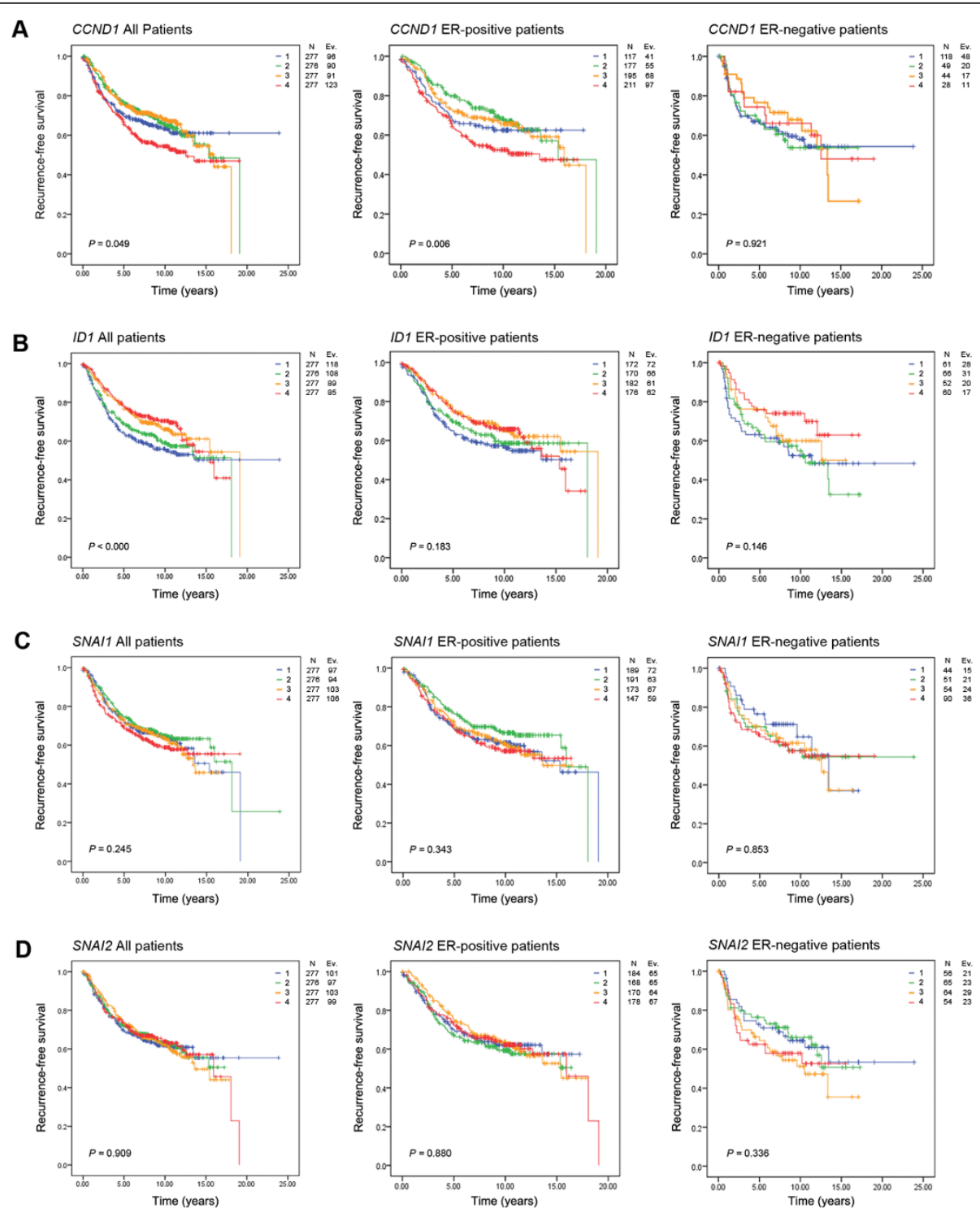

Figure 3 Correlation of CCND1, ID1, SNAI1 and SNAI2 expression to recurrence free survival. Expression of our genes of interest in relation to recurrence-free survival was examined in a breast cancer database containing 1,107 tumours from Sims et al. (2008). Gene expression intensity was quartiled as 1-low, 2- medium low, 3-medium high and 4- high, and assessed in all patients, ER-positive and ER-negative patients, respectively (A) CCND1 quartiles (B) ID1 quartiles (C) SNAI1 quartiles (D) SNAI2 quartiles. P-value is based on log-rank test.

expressing tumours (Figure 5D-F). These data are consistent with our observation that $C C N D 1^{\text {low }} / I D 1^{\text {high }}$ tumours belong to a subgroup of breast tumours with distinct expression pattern of CCND1, ID1 and EMT related genes.

\section{Discussion}

In this study we demonstrate that the increase in MDAMB-231 cell migration following cyclin D1 silencing is dependent on the upregulation of Id1. Previous studies have found both similarities and differences to our experimental model. Caldon et al. showed an increase in Id1 protein in mouse mammary epithelial cells isolated from cyclin $\mathrm{D} 1^{-1-}$ mice compared to wild type, in line with our observations. Moreover, they also established the inability of Id1 to promote proliferation of mammary acini in the absence of cyclin D1 [43]. Swarbrick et al. revealed a decrease in cyclin D1 expression $48 \mathrm{~h}$ after Id1 silencing in MCF7 cells [44], and others report the same effect in both MCF7 and MDA-MB-231 cells [45]. We did not observe this decrease in cyclin D1 protein expression in MDA-MB-231 cells after $24 \mathrm{~h}$ in our study. However, qPCR analysis showed a similar decrease in cyclin D1 mRNA levels which may become 
A

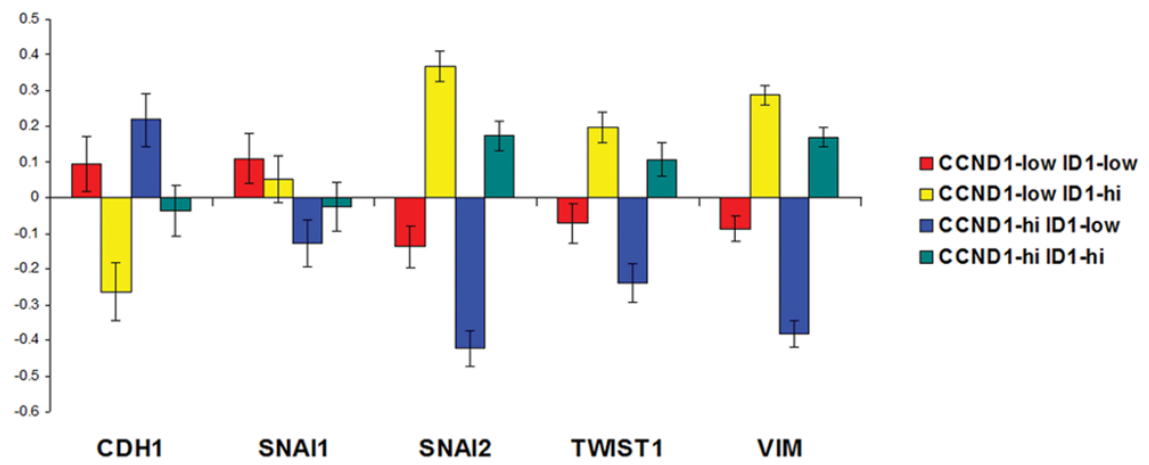

B
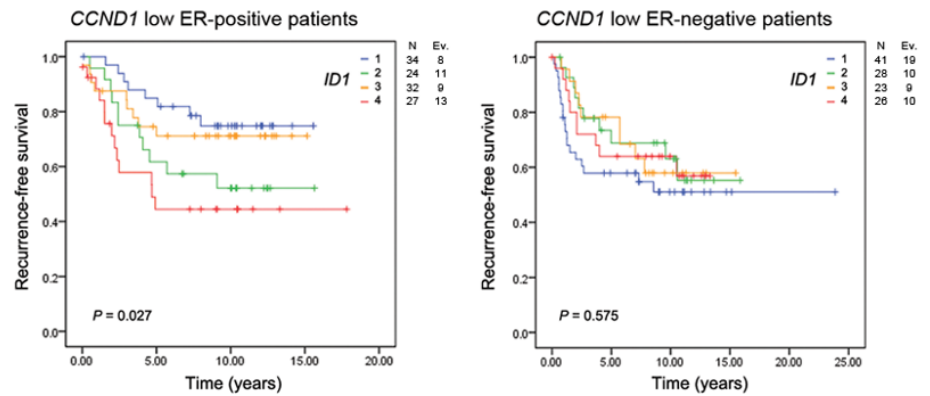

C
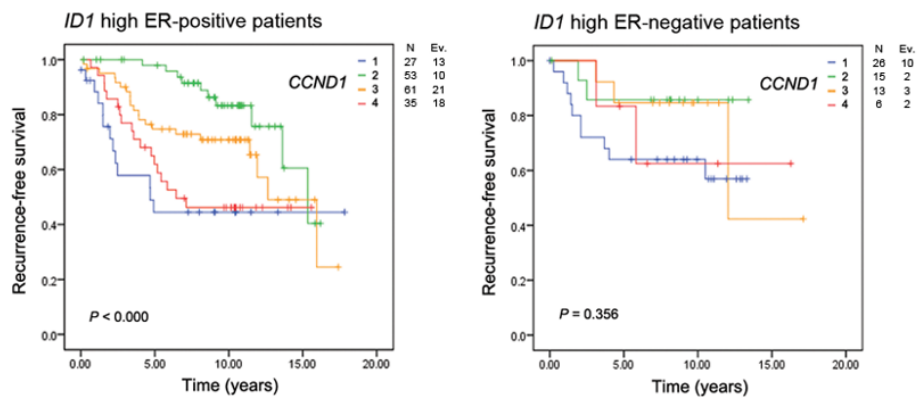

Figure 4 EMT-related gene expression intensity and recurrence free survival in CCND1/ID1 high and low tumours. A breast cancer database was employed to examine (A) Mean-centered average expression of EMT-related genes of interest in CCND1/ID1 subgroups, and (B, C) Recurrence-free survival of ER-positive and negative patients in CCND1/ID1 subgroups. P-value is based on log-rank test.

more apparent on the protein level after $48 \mathrm{~h}$. Bienvenu et al. demonstrated binding of cyclin D1 to the promoter region of ID1 in mouse retinal cells, and when comparing wildtype to $C C N D 1^{-1-}$ mice found an 8 -fold enrichment of IDI. We have also observed occupancy of the Id1 promoter region by cyclin D1 in MDA-MB-231 cells, where it may repress Id1 expression. These data demonstrate the complex relationship between cyclin D1 and Id1. It is important to note that here we are only proposing this mechanism in MDA-MB-231 cells and in a distinct subset of representative breast tumours. We observed this complexity during the course of our work, where despite an increase in ZR75-1 migration following cyclin D1 silencing, Id1 protein levels were so low as to not substantially contribute to this effect. We postulate that in ZR75-1 cells other known transcription regulators of Id1 such as TGF-beta may be responsible for repressing expression of the protein. Importantly, TGF-beta and other known Id1 regulators (KLF17, Src) were unchanged in our MDA-MB-231 microarray following cyclin D1 silencing, indicating they do not contribute to the upregulation of Id1 or migration in our analysis.

It is pertinent to highlight that the increase in migration we have observed is occurring in an already highly invasive, mesenchymal-like cell line. This may account for a lessened migratory response to cyclin D1 silencing. Further evidence of this concept is shown in the more epithelial-like, less typically invasive ZR75-1 cells, where the increase in cell migration is more pronounced (1.89 


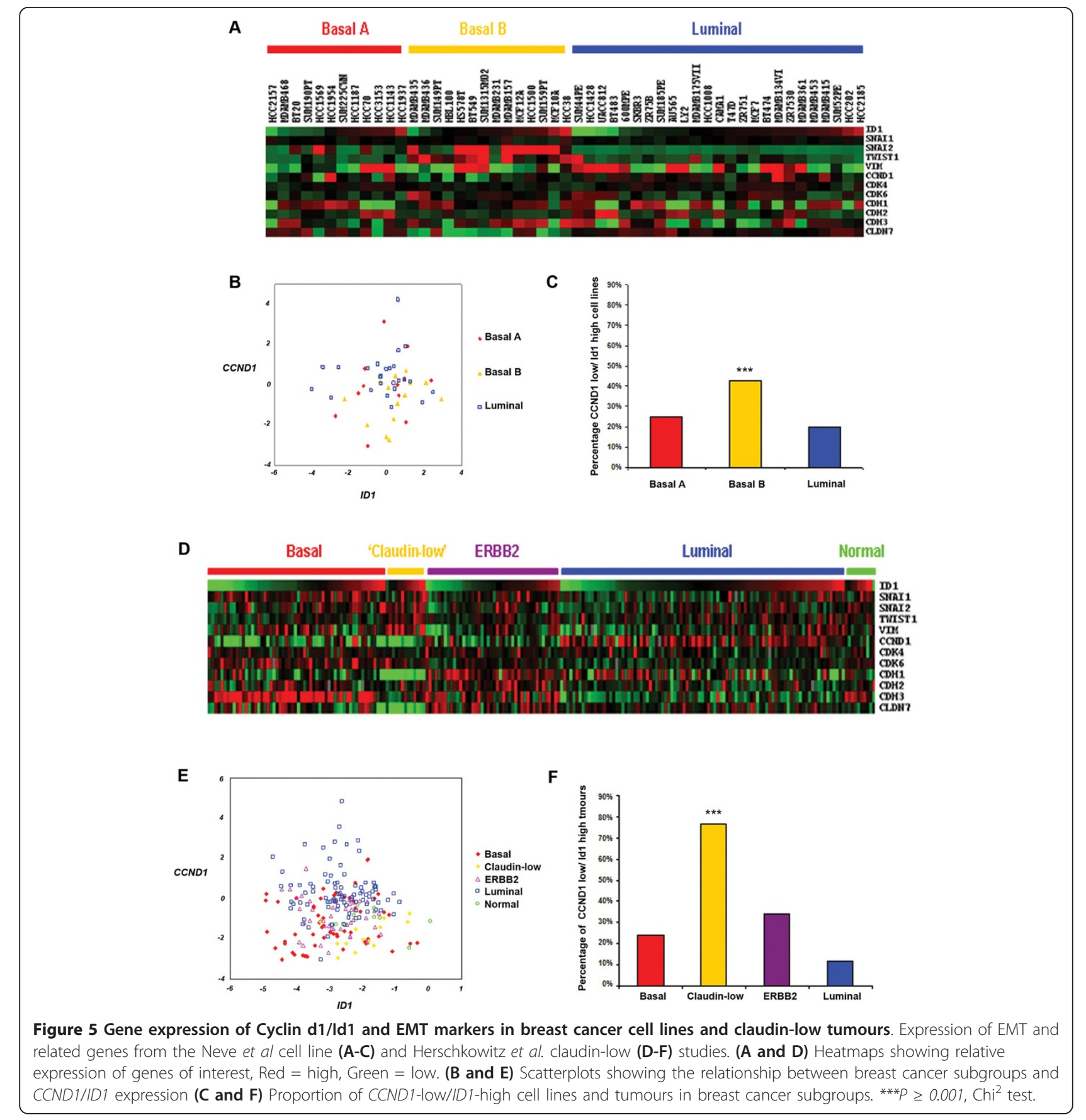

fold vs. 1.3 fold in MDA-MB-231) following cyclin D1 knock-down. In addition, cyclin D1 is known to be expressed at variable levels across cell lines and subtypes of breast cancer thus, silencing of cyclin D1 is unlikely to increase migration uniformly in all cell types.

A common feature in our MDA-MB-231 and ZR75-1 cells was an increase in SNAI2 expression $24 \mathrm{~h}$ after cyclin D1 knock-down, which coincided with an increase in cell migration. In MDA-MB-231 cells, silencing of Id1 reversed this and SNAI2 expression was decreased, as was cell migration. Moreover, silencing of Slug- the SNAI2 protein, significantly decreased MDA-MB-231 migration, and cyclin D1 silencing was unable to rescue this effect. These migratory observations for SNAI2 are in line with previous experimental data, indicating that Slug expression induces a migratory phenotype and can represses E-cadherin, inducing an EMT in epithelial cells [46]. Moreover, siRNA against Slug decreases MDA-MB-231 cell migration [47], and Slug and Snail are overexpressed invasive 
ductal carcinoma [48]- a form of breast cancer hallmarked by cell migration. In our experimental model, Slug would appear a likely candidate mediating the observed migratory effects, however it is entirely plausible that it does so in conjunction with other EMT factors. We also found statistically significant changes in TWIST1 and CDH11 (the positive EMT-regulator also known as OB-cadherin) following cyclin D1 silencing, both of which have been implicated with enhanced cell motility $[49,50]$. The changes in our EMT markers are in the order of 1.13 to 1.19 fold of control by expression array analysis (Figure 2A). We note that these figures are more meaningful when taken in the context of the most increased gene in our expression array, which was only upregulated 1.8 fold [14]. As may be expected from treatment with siRNA, many more genes were downregulated in the array analysis than upregulated, again highlighting the importance of the increases in our mesenchymal markers. It is likely that all of these factors work in concert to promote a migratory and EMT-like phenotype, and that small gains in expression of a number of EMT genes can contribute to a greater overall effect.

The relationship between cyclin D1 expression and patient outcome remains a controversial area, with studies reporting both positive and negative associations. CCND1 gene amplification has been related to poor disease outcome in ER-positive patients [51,52], but others correlate cyclin D1 protein expression with both better $[53,54]$ and worse [55] prognosis. It has been proposed that subgroup analysis with small numbers of patients [56] and splice variants of the gene have contributed to these contrasting results. In agreement with others [57], we found an association between high CCND1 expression and poor prognosis (Figure 3A). However, when examining ID1 high tumours, both the highest and lowest expression quartiles of CCND1 were correlated to reduced RFS/DFS but only in the ER-positive subgroup (Figure 4C). A similar trend was noted for ID1, where in all patients low expression of the gene was associated with a shortest RFS (Figure 3B), but in the CCND1 low ER-positive subgroup of tumours, a positive correlation was found (Figure 4B).

Whilst this may appear contrasting to our in vitro data, we reason that cyclin D1 low, ER-positive tumours best represent our cell line model. We chose two cell lines (MDA-MB-231 and ZR75-1) based on their high expression of cyclin D1 (regardless of oestrogen receptor status). We then reduced these high levels using siRNA and noted an increase in cell migration and EMT markers. As ER-negative tumours are consistently cyclin D1 low, these are less representative our in vitro experiments. ER-positive tumours however are typically cyclin D1 high, thus by choosing tumours that are cyclin D1 low in this subgroup, we are more correctly mimicking our in vitro setting, where expression of cyclin D1 may have been lost. This yields the interesting observation that ER-positive tumours with low cyclin D1 appear to behave similarly to ER-negative tumours with regards to their relationship to EMT markers and the claudin-low subtype. Thus, should ER-positive tumours that have lost expression of cyclin D1 be considered more ERnegative-like? Whilst the answer to this question is far beyond the scope of this study, what is clear is that the effect we are observing is centred on loss of cyclin D1 and not on the oestrogen receptor status of our testing material.

Interestingly, the $C C N D 1^{\text {low }} / I D 1^{\text {high }}$ and $C C N D 1^{\text {high }} /$ $I D 1^{\text {high }}$ tumours both displayed increased expression of EMT-related genes (Figure 4A, yellow and green bars respectively). This suggests that in the context of these subgroups, ID1 is vital for increased EMT gene expression and when CCND1 is low it enhances the EMT phenotype.

We did not observe any meaningful impact of EMT genes in individual Kaplin-meier analysis on patient survival in our dataset. There has been an explosion of EMT related data in recent years in the breast cancer field. Central to many of these publications has been the ability of EMT to putatively enhance stem cell-related features and promote the metastatic process $[58,59]$. Of particular note, the idea of cells that have undergone EMT residing at the leading edge of an invasive tumour and promoting metastasis at the tumour-stroma interface has garnered much attention [60]. This hypothesis may be one explanation as to why EMT markers such as SNAI1, SNAI2, TWIST1 and VIM do not show any prognostic significance in our model- if the cells that have undergone EMT reside at the leading edge of the tumour, strong expression of their genes could easily be lost amongst the entirety of the tumour body. In these circumstances, any strong links to prognosis would also be diluted.

A second, more straightforward explanation as to why we have not observed prognostic significance of EMTrelated genes centers upon a keystone principal. Upregulation of one EMT gene, e.g. SNAI1, is not enough to induce a transition to mesenchymal phenotype. This is supported by the board range of expression values of EMT genes across all breast cancer tumours and subtypes in our study (Figure 5D). Induction of EMT requires a reduction in $C D H 1$ expression and upregulation of the potent SNAI1, SNAI2 and TWIST1 genes (amongst others). In order to examine the effect of EMT in our cohort, we would have to combine all tumours with these gene properties- giving us a 'claudin-low' subgroup. Unfortunately, we have too few cases in our claudin-low dataset to give any relevant 
prognostic information. In order to explore this further a cohort consisting of a large representation of claudinlow tumours, preferably with micro-dissection of the tumour-stroma interface would be required.

Much like CCND1, some controversy surrounds expression patterns of $I D 1$, and despite numerous links to invasion and migration in breast cancer $[43,44]$ some groups report an absence of the protein in the normal mammary gland [61]. Perk et al. assessed Id1 protein expression in mammary carcinomas [62] and found nuclear expression of Id1 in a rare subtype of breast cancer, metaplastic mammary tumours. Metaplastic cancers have a unique genetic profile that is notably, most closely related to the claudin-low subtype of breast cancer $[41,63,64]$ and are very poorly differentiated. Given the poor outcome associated with metaplastic cancer, it may indicate why high ID1 expression in CCND1 low tumours gave the shortest RFS.

Adding further weight to our analysis, we found the greatest proportion of $C C N D 1^{\text {low }} / I D 1^{\text {high }}$ cell lines and tumours in the claudin-low subgroup, which have a poor prognosis [65], associations with EMT and chemotherapy resistance [66] and has stem-cell tumour initiating features [42]. A number of these properties are reflected in both the cell lines and patient material used within this study, potentially indicating a central role for cyclin D1 and Id1 in this subgroup.

\section{Conclusions}

The increase in MDA-MB-231 migration we have observed following cyclin D1 silencing is dependent on an upregulation of $\operatorname{Id} 1$ and induction of a more mesenchymal phenotype. Patients with $C C N D 1^{\text {low }} /$ $I D 1^{\text {high }}$ tumours have a shorter RFS and we have shown a link between $C C N D 1^{\text {low }} / I D 1^{\text {high }}$ tumours and the claudin-low subgroup of breast cancer.

\section{Additional material}

Additional file 1: qPCR primers. Sequences of primers used in this

study.

Additional file 2: TGF- $\beta$ gene expression in breast cancer cell lines.

The dataset from Neve et al. was employed to examine TGF- $\beta$ gene expression in breast cancer cell lines. The bar at the bottom of the figure represents the subtype of each cell line. Blue $=$ luminal, Orange $=$ Basal $\mathrm{A}$, Red $=$ Basal B. Cell lines of interest are highlighted with a black rectangle, and are ZR75-1 and MDA-MB-231 cell.

Additional file 3: Cyclin D1 silencing does not increase MDA-MB231 cell migration in the absence of Slug. Actively cycling MDA-MB231 cells were monitored $20 \mathrm{~h}$ post-transfection with the indicated siRNA (cyclin D1/slug) for changes in cell migration and gene expression. Error bars represent standard deviation. (A) Cell migration as measured by Boyden chamber assay (B) qPCR analysis of slug expression. ${ }^{* *} P \geq 0.001$, ${ }^{*} P \geq 0.01,{ }^{*} P \geq 0.05$ vs. control, two-tailed student's t-test.

Additional file 4: Correlation of CDH1, VIM and TWIST1 expression to recurrence free survival. Expression of our genes of interest in relation to recurrence free survival was examined in a breast cancer meta-analysis. (A) CDH1 quartiles (B) VIM quartiles (C) TWIST1 quartiles. Pvalue is based on log-rank test.

\section{Acknowledgements and funding}

We wish to thank Prof. Anthony Howell for contributions to the editing process. This study was supported by grants from the Swedish Cancer Society, the Swedish Research Council, the Knut and Alice Wallenberg Foundation, Malmö University Hospital Research and Cancer Funds, Lund University Research Funds, South Swedish and South-East Swedish Breast Cancer groups and Breakthrough Breast Cancer Unit, Manchester, UK. AHS is also grateful for funding from Breakthrough Breast Cancer. The funders had no role in study design, data collection and analysis, decision to publish, or preparation of the manuscript.

\section{Author details}

'Breakthrough Breast Cancer Research Unit, School of Cancer, Enabling Sciences and Technology, University of Manchester, Manchester Academic Health Science Centre, Paterson Institute for Cancer Research, The Christie NHS Foundation Trust, Wilmslow Road, Manchester, M20 4BX, UK. ${ }^{2}$ Cancer Center Karolinska, Karolinska Institute and University Hospital, Stockholm, S17176, Sweden. ${ }^{3}$ Applied Bioinformatics of Cancer, Breakthrough Breast Cancer Research Unit, Edinburgh Cancer Research Centre, Institute of Genetics and Molecular Medicine, Crewe Road South Edinburgh, EH4 2XR, UK. ${ }^{4}$ Department of Laboratory Medicine, Center for Molecular Pathology, Lund University, Malmö University Hospital, Malmö, SE-205 02, Sweden.

\section{Authors' contributions}

NT performed the experimental work and the statistical analyses as well as drafting the manuscript. KL helped with the experimental work, and statistical analysis as well as drafting the manuscript. SL performed migration assays and western blots. AHS performed the statistical analyses and the bioinformatics related experimental work, as well as drafting the manuscript. $G L$ was the principal investigator of the study and participated in the study design and interpretation of the data and helped to draft the manuscript. All authors read and approved the final manuscript.

\section{Competing interests}

The authors declare that they have no competing interests.

Received: 4 April 2011 Accepted: 28 September 2011

Published: 28 September 2011

\section{References}

1. Kato J, Matsushime H, Hiebert SW, Ewen ME, Sherr CJ: Direct binding of cyclin $\mathrm{D}$ to the retinoblastoma gene product $(\mathrm{pRb})$ and $\mathrm{pRb}$ phosphorylation by the cyclin D-dependent kinase CDK4. Genes Dev 1993, 7(3):331-342.

2. Lundberg AS, Weinberg RA: Functional inactivation of the retinoblastoma protein requires sequential modification by at least two distinct cyclincdk complexes. Mol Cell Biol 1998, 18(2):753-761.

3. Weinberg RA: The retinoblastoma protein and cell cycle control. Cell 1995, 81(3):323-330.

4. Jiang W, Kahn SM, Zhou P, Zhang YJ, Cacace AM, Infante AS, Doi S, Santella RM, Weinstein IB: Overexpression of cyclin D1 in rat fibroblasts causes abnormalities in growth control, cell cycle progression and gene expression. Oncogene 1993, 8(12):3447-3457.

5. Lammie GA, Fantl V, Smith R, Schuuring E, Brookes S, Michalides R, Dickson C, Arnold A, Peters G: D11S287, a putative oncogene on chromosome 11q13, is amplified and expressed in squamous cell and mammary carcinomas and linked to BCL-1. Oncogene 1991, 6(3):439-444.

6. Wang TC, Cardiff RD, Zukerberg L, Lees E, Arnold A, Schmidt EV: Mammary hyperplasia and carcinoma in MMTV-cyclin D1 transgenic mice. Nature 1994, 369(6482):669-671.

7. Zhou P, Jiang W, Zhang YJ, Kahn SM, Schieren I, Santella RM, Weinstein IB: Antisense to cyclin D1 inhibits growth and reverses the transformed phenotype of human esophageal cancer cells. Oncogene 1995, 11(3):571-580. 
8. Jares P, Rey MJ, Fernandez PL, Campo E, Nadal A, Munoz M, Mallofre C, Muntane J, Nayach I, Estape J, et al: Cyclin D1 and retinoblastoma gene expression in human breast carcinoma: correlation with tumour proliferation and oestrogen receptor status. J Pathol 1997, 182(2):160-166.

9. Sutter T, Doi S, Carnevale KA, Arber N, Weinstein IB: Expression of cyclins D1 and E in human colon adenocarcinomas. J Med 1997, 28(5-6):285-309.

10. Drobnjak M, Osman I, Scher HI, Fazzari M, Cordon-Cardo C: Overexpression of cyclin D1 is associated with metastatic prostate cancer to bone. Clin Cancer Res 2000, 6(5):1891-1895.

11. Coqueret O: Linking cyclins to transcriptional control. Gene 2002, 299(12):35-55.

12. Zwijsen RM, Wientjens E, Klompmaker R, van der Sman J, Bernards R, Michalides RJ: CDK-independent activation of estrogen receptor by cyclin D1. Cell 1997, 88(3):405-415.

13. Bienvenu F, Jirawatnotai S, Elias JE, Meyer CA, Mizeracka K, Marson A, Frampton GM, Cole MF, Odom DT, Odajima J, et al: Transcriptional role of cyclin D1 in development revealed by a genetic-proteomic screen. Nature 2010, 463(7279):374-378.

14. Lehn S, Tobin NP, Berglund P, Nilsson K, Sims AH, Jirstrom K, Harkonen P, Lamb R, Landberg G: Downregulation of the Oncogene Cyclin D1 Increases Migratory Capacity in Breast Cancer and Is Linked to Unfavorable Prognostic Features. Am J Pathol 2010.

15. Ephrussi A, Church GM, Tonegawa S, Gilbert W: B lineage-specific interactions of an immunoglobulin enhancer with cellular factors in vivo. Science 1985, 227(4683):134-140.

16. Benezra R, Davis RL, Lockshon D, Turner DL, Weintraub H: The protein Id: a negative regulator of helix-loop-helix DNA binding proteins. Cell 1990, 61(1):49-59.

17. Singh J, Murata K, Itahana $Y$, Desprez PY: Constitutive expression of the Id1 promoter in human metastatic breast cancer cells is linked with the loss of NF-1/Rb/HDAC-1 transcription repressor complex. Oncogene 2002, 21(12):1812-1822.

18. Lin CQ, Singh J, Murata K, Itahana Y, Parrinello S, Liang SH, Gillett CE, Campisi J, Desprez PY: A role for Id-1 in the aggressive phenotype and steroid hormone response of human breast cancer cells. Cancer Res 2000, 60(5):1332-1340

19. Fong $S$, Itahana $Y$, Sumida T, Singh J, Coppe JP, Liu Y, Richards PC, Bennington $\mathrm{J}$, Lee NM, Debs RJ, et al: Id-1 as a molecular target in therapy for breast cancer cell invasion and metastasis. Proc Natl Acad Sci USA 2003, 100(23):13543-13548.

20. Hay ED: The mesenchymal cell, its role in the embryo, and the remarkable signaling mechanisms that create it. Dev Dyn 2005, 233(3):706-720.

21. Trimboli AJ, Fukino K, de Bruin A, Wei G, Shen L, Tanner SM, Creasap N, Rosol TJ, Robinson ML, Eng C, et al: Direct evidence for epithelialmesenchymal transitions in breast cancer. Cancer Res 2008, 68(3):937-945.

22. Micalizzi DS, Farabaugh SM, Ford HL: Epithelial-mesenchymal transition in cancer: parallels between normal development and tumor progression. J Mammary Gland Biol Neoplasia 2010, 15(2):117-134.

23. Ikenouchi J, Matsuda M, Furuse M, Tsukita S: Regulation of tight junctions during the epithelium-mesenchyme transition: direct repression of the gene expression of claudins/occludin by Snail. J Cell Sci 2003, 116(Pt 10):1959-1967.

24. Ozdamar B, Bose R, Barrios-Rodiles M, Wang HR, Zhang Y, Wrana JL: Regulation of the polarity protein Par6 by TGFbeta receptors controls epithelial cell plasticity. Science 2005, 307(5715):1603-1609.

25. Hajra KM, Chen DY, Fearon ER: The SLUG zinc-finger protein represses Ecadherin in breast cancer. Cancer Res 2002, 62(6):1613-1618.

26. Li Y, Yang J, Luo JH, Dedhar S, Liu Y: Tubular epithelial cell dedifferentiation is driven by the helix-loop-helix transcriptional inhibitor Id1. J Am Soc Nephrol 2007, 18(2):449-460.

27. Gumireddy K, Li A, Gimotty PA, Klein-Szanto AJ, Showe LC, Katsaros D, Coukos G, Zhang L, Huang Q: KLF17 is a negative regulator of epithelialmesenchymal transition and metastasis in breast cancer. Nat Cell Biol 2009, 11(11):1297-1304.

28. Berglund $P$, Stighall M, Jirstrom K, Borgquist S, Sjolander A, Hedenfalk I, Landberg G: Cyclin E overexpression obstructs infiltrative behavior in breast cancer: a novel role reflected in the growth pattern of medullary breast cancers. Cancer Res 2005, 65(21):9727-9734

29. Sims AH, Smethurst GJ, Hey Y, Okoniewski MJ, Pepper SD, Howell A, Miller CJ, Clarke RB: The removal of multiplicative, systematic bias allows integration of breast cancer gene expression datasets - improving metaanalysis and prediction of prognosis. BMC Med Genomics 2008, 1:42

30. Herschkowitz JI, Simin K, Weigman VJ, Mikaelian I, Usary J, Hu Z, Rasmussen KE, Jones LP, Assefnia S, Chandrasekharan S, et al: Identification of conserved gene expression features between murine mammary carcinoma models and human breast tumors. Genome Biol 2007, 8(5):R76.

31. Neve RM, Chin K, Fridlyand J, Yeh J, Baehner FL, Fevr T, Clark L, Bayani N, Coppe JP, Tong F, et al: A collection of breast cancer cell lines for the study of functionally distinct cancer subtypes. Cancer Cell 2006, 10(6):515-527.

32. Liang $Y Y$, Brunicardi $F C$, Lin $X:$ Smad3 mediates immediate early induction of Id1 by TGF-beta. Cell research 2009, 19(1):140-148.

33. Gumireddy K, Li A, Gimotty PA, Klein-Szanto AJ, Showe LC, Katsaros D, Coukos G, Zhang L, Huang Q: KLF17 is a negative regulator of epithelialmesenchymal transition and metastasis in breast cancer. Nature cell biology 2009, 11(11):1297-1304.

34. Gautschi O, Tepper CG, Purnell PR, Izumiya Y, Evans CP, Green TP, Desprez PY, Lara PN, Gandara DR, Mack PC, et al: Regulation of Id1 expression by SRC: implications for targeting of the bone morphogenetic protein pathway in cancer. Cancer research 2008, 68(7):2250-2258

35. Fu J, Qin L, He T, Qin J, Hong J, Wong J, Liao L, Xu J: The TWIST/Mi2/NuRD protein complex and its essential role in cancer metastasis. Cell Res 2010.

36. Gilles C, Polette M, Zahm JM, Tournier JM, Volders L, Foidart JM, Birembaut P: Vimentin contributes to human mammary epithelial cell migration. J Cell Sci 1999, 112(Pt 24):4615-4625.

37. Charafe-Jauffret E, Ginestier C, lovino F, Wicinski J, Cervera N, Finetti $P$, Hur MH, Diebel ME, Monville F, Dutcher J, et al: Breast cancer cell lines contain functional cancer stem cells with metastatic capacity and a distinct molecular signature. Cancer Res 2009, 69(4):1302-1313.

38. Kao J, Salari K, Bocanegra M, Choi YL, Girard L, Gandhi J, Kwei KA, Hernandez-Boussard T, Wang P, Gazdar AF, et al: Molecular profiling of breast cancer cell lines defines relevant tumor models and provides a resource for cancer gene discovery. PLoS One 2009, 4(7):e6146.

39. Lapuk A, Marr H, Jakkula L, Pedro H, Bhattacharya S, Purdom E, Hu Z, Simpson K, Pachter L, Durinck $S$, et al: Exon-level microarray analyses identify alternative splicing programs in breast cancer. Mol Cancer Res 2010, 8(7):961-974.

40. Creighton CJ, Chang JC, Rosen JM: Epithelial-mesenchymal transition (EMT) in tumor-initiating cells and its clinical implications in breast cancer. J Mammary Gland Biol Neoplasia 2010, 15(2):253-260.

41. Prat A, Parker JS, Karginova O, Fan C, Livasy C, Herschkowitz Jl, He X, Perou CM: Phenotypic and molecular characterization of the claudin-low intrinsic subtype of breast cancer. Breast Cancer Res 2010, 12(5):R68.

42. Creighton CJ, Li X, Landis M, Dixon JM, Neumeister VM, Sjolund A, Rimm DL, Wong H, Rodriguez A, Herschkowitz Jl, et al: Residual breast cancers after conventional therapy display mesenchymal as well as tumor-initiating features. Proc Natl Acad Sci USA 2009, 106(33):13820-13825

43. Caldon CE, Swarbrick A, Lee CS, Sutherland RL, Musgrove EA: The helixloop-helix protein Id 1 requires cyclin $\mathrm{D} 1$ to promote the proliferation of mammary epithelial cell acini. Cancer Res 2008, 68(8):3026-3036.

44. Swarbrick A, Akerfeldt MC, Lee CS, Sergio CM, Caldon CE, Hunter LJ, Sutherland RL, Musgrove EA: Regulation of cyclin expression and cell cycle progression in breast epithelial cells by the helix-loop-helix protein Id1. Oncogene 2005, 24(3):381-389.

45. Lee JY, Kang MB, Jang SH, Qian T, Kim HJ, Kim CH, Kim Y, Kong G: Id-1 activates Akt-mediated Wnt signaling and p27(Kip1) phosphorylation through PTEN inhibition. Oncogene 2009, 28(6):824-831.

46. Chen H, Zhu G, Li Y, Padia RN, Dong Z, Pan ZK, Liu K, Huang S: Extracellular signal-regulated kinase signaling pathway regulates breast cancer cell migration by maintaining slug expression. Cancer Res 2009, 69(24):9228-9235.

47. Bolos V, Peinado H, Perez-Moreno MA, Fraga MF, Esteller M, Cano A: The transcription factor Slug represses E-cadherin expression and induces epithelial to mesenchymal transitions: a comparison with Snail and E47 repressors. J Cell Sci 2003, 116(Pt 3):499-511.

48. Come C, Magnino F, Bibeau F, De Santa Barbara P, Becker KF, Theillet C, Savagner P: Snail and slug play distinct roles during breast carcinoma progression. Clin Cancer Res 2006, 12(18):5395-5402. 
49. Mironchik $Y$, Winnard PT Jr, Vesuna F, Kato $Y$, Wildes F, Pathak AP, Kominsky S, Artemov D, Bhujwalla Z, Van Diest P, et al: Twist overexpression induces in vivo angiogenesis and correlates with chromosomal instability in breast cancer. Cancer Res 2005, 65(23):10801-10809.

50. Nakajima G, Patino-Garcia A, Bruheim S, Xi Y, San Julian M, Lecanda F, Sierrasesumaga L, Muller C, Fodstad O, Ju J: CDH11 expression is associated with survival in patients with osteosarcoma. Cancer Genomics Proteomics 2008, 5(1):37-42.

51. Berns EM, Foekens JA, van Staveren IL, van Putten $W L$, de Koning HY, Portengen $\mathrm{H}$, Klijn JG: Oncogene amplification and prognosis in breast cancer: relationship with systemic treatment. Gene 1995, 159(1):11-18.

52. Bieche I, Olivi M, Nogues C, Vidaud M, Lidereau R: Prognostic value of CCND1 gene status in sporadic breast tumours, as determined by realtime quantitative PCR assays. Br J Cancer 2002, 86(4):580-586.

53. Gillett C, Smith P, Gregory W, Richards M, Millis R, Peters G, Barnes D: Cyclin D1 and prognosis in human breast cancer. Int J Cancer 1996, 69(2):92-99.

54. Hwang TS, Han HS, Hong YC, Lee HJ, Paik NS: Prognostic value of combined analysis of cyclin D1 and estrogen receptor status in breast cancer patients. Pathol Int 2003, 53(2):74-80.

55. Han S, Park K, Bae BN, Kim KH, Kim HJ, Kim YD, Kim HY: Cyclin D1 expression and patient outcome after tamoxifen therapy in estrogen receptor positive metastatic breast cancer. Oncol Rep 2003, 10(1):141-144.

56. Taneja P, Maglic D, Kai F, Zhu S, Kendig RD, Fry EA, Inoue K: Classical and Novel Prognostic Markers for Breast Cancer and their Clinical Significance. Clin Med Insights Oncol 2010, 4:15-34.

57. Kenny FS, Hui R, Musgrove EA, Gee JM, Blamey RW, Nicholson Rl, Sutherland RL, Robertson JF: Overexpression of cyclin D1 messenger RNA predicts for poor prognosis in estrogen receptor-positive breast cancer. Clin Cancer Res 1999, 5(8):2069-2076.

58. Mimeault M, Batra SK: Functions of tumorigenic and migrating cancer progenitor cells in cancer progression and metastasis and their therapeutic implications. Cancer Metastasis Rev 2007, 26(1):203-214.

59. Mimeault M, Batra SK: Interplay of distinct growth factors during epithelial mesenchymal transition of cancer progenitor cells and molecular targeting as novel cancer therapies. Ann Oncol 2007, 18(10):1605-1619.

60. Blick T, Widodo E, Hugo H, Waltham M, Lenburg ME, Neve RM, Thompson EW: Epithelial mesenchymal transition traits in human breast cancer cell lines. Clin Exp Metastasis 2008, 25(6):629-642.

61. Uehara N, Chou YC, Galvez JJ, de-Candia P, Cardiff RD, Benezra R, Shyamala G: Id-1 is not expressed in the luminal epithelial cells of mammary glands. Breast Cancer Res 2003, 5(2):R25-29.

62. Perk J, Gil-Bazo I, Chin Y, de Candia P, Chen JJ, Zhao Y, Chao S, Cheong W, Ke $Y$, Al-Ahmadie $\mathrm{H}$, et al: Reassessment of id1 protein expression in human mammary, prostate, and bladder cancers using a monospecific rabbit monoclonal anti-id1 antibody. Cancer Res 2006, 66(22):10870-10877.

63. Hennessy BT, Gonzalez-Angulo AM, Stemke-Hale K, Gilcrease MZ, Krishnamurthy S, Lee JS, Fridlyand J, Sahin A, Agarwal R, Joy C, et al: Characterization of a naturally occurring breast cancer subset enriched in epithelial-to-mesenchymal transition and stem cell characteristics. Cancer Res 2009, 69(10):4116-4124.

64. Weigelt B, Kreike B, Reis-Filho JS: Metaplastic breast carcinomas are basallike breast cancers: a genomic profiling analysis. Breast Cancer Res Treat 2009, 117(2):273-280.

65. Luini A, Aguilar M, Gatti G, Fasani R, Botteri E, Brito JA, Maisonneuve P, Vento AR, Viale G: Metaplastic carcinoma of the breast, an unusual disease with worse prognosis: the experience of the European Institute of Oncology and review of the literature. Breast Cancer Res Treat 2007, 101(3):349-353.

66. Farmer $\mathrm{P}$, Bonnefoi $\mathrm{H}$, Anderle $\mathrm{P}$, Cameron D, Wirapati $\mathrm{P}$, Becette $\mathrm{V}$, Andre S, Piccart M, Campone M, Brain E, et al: A stroma-related gene signature predicts resistance to neoadjuvant chemotherapy in breast cancer. Nat Med 2009, 15(1):68-74.

Pre-publication history

The pre-publication history for this paper can be accessed here: http://www.biomedcentral.com/1471-2407/11/417/prepub

\section{Submit your next manuscript to BioMed Central and take full advantage of:}

- Convenient online submission

- Thorough peer review

- No space constraints or color figure charges

- Immediate publication on acceptance

- Inclusion in PubMed, CAS, Scopus and Google Scholar

- Research which is freely available for redistribution

Submit your manuscript at www.biomedcentral.com/submit 